\title{
Assessment of Angiosperm taxa at Bharsar and its adjoining area of district Pauri Garhwal, Uttarakhand, India with emphasis on ethnomedicinal uses
}

\author{
ANAND SINGH BISHT \\ VCSG Uttarakhand University of Horticulture and Forestry. Bharsar, District of Pauri Garhwal, Uttarakhand 246123, India. `email: \\ drbishtas@gmail.com
}

Manuscript received: 5 April 2017. Revision accepted: 9 June 2017.

\begin{abstract}
Bisht AS. 2017. Assessment of Angiosperm taxa at Bharsar and its adjoining area of district Pauri Garhwal, Uttarakhand, India with emphasis on ethnomedicinal uses. Asian J For 1: 1-17. The Himalayas region becomes an enigma for various aspects including biological diversity. Bharsar region, district Pauri Garhwal, Uttarakhand, India is a biologically important region in the Himalaya, yet there is limited information on the flora diversity comprised in this region. This paper aimed to reveal the biological diversity of plants within Angiosperm in the Bharsar region. Botanical surveys were conducted in Bharsar and its adjoining area from December 2014 to December 2016. A total of 75 families and 274 species of Angiosperm plant were recorded during the study period with 237 species were dicotyledons (66 families), and 37 species of monocotyledons (9 families). Out of the 75 angiosperms families, Asteraceae contributed the highest with $13.14 \%$ (36 species), followed by Fabaceae $6.16 \%$ (17 species), Lamiaceae and Rosaceae both $5.43 \%$ (15 species), Poaceae 4.71\%, Ranunculaceae $4.35 \%$ (12 species), Polygonaceae $4.04 \%$ (11 species). The people in this region use a variety of plant species for various purposes including medicine, food, fuel, and fodder. Bharsar happens to be one of the newly developed areas and experiences different types of biotic pressure of plant life which are especially accelerating with the process of developmental activities. This study serves as baseline information for future studies including those aiming to monitor the biodiversity in Bharsar region.
\end{abstract}

Keywords: Angiosperm, Bharsar, diversity, flora, Garhwal, Himalaya, medicinal plants

\section{INTRODUCTION}

The Himalayas is the pivotal source of attractions, curiosity, and challenge to human intellect through the ages. Amongst several aspects of the Himalayas, the vegetation provides an everlasting and interesting field of investigation. The diversity, copiousness, as well as uniqueness of the plant components in various habitats, retained sound and aesthetic environment of the Himalayas. However, in recent decades, excessive exploitation of vegetation, unplanned land use, natural disasters, and several developmental processes, have accelerated the deterioration of vegetation or loss of individual species. This situation is worsened since there is a limited detailed botanical record for several of the localities or regions. One of such botanical interests is located in a little-known region in the Bharsar in district Pauri, which sustains unique and rich genetic resources.

In view of the multiple stresses and depletion of genetic resources and habitat, today's foremost concern of the globe in general and Himalayas, in particular, is the conservation of biological diversity, for which detailed descriptions of plant genetic entities are essential. Keeping in view: (i) the diversity and richness of biological resources in vast and varied stretch of land; (ii) the lack of earlier record; (iii) the deterioration of mountain ecosystem; and (iv) present-day concern of biodiversity, an attempt is made to reveal the biological diversity of plant within Angiosperm in the Bharsar region of District Pauri Garhwal, Uttarakhand, India.

\section{MATERIALS AND METHODS}

\section{Study area}

The present study was carried out in the temperate regions of Bharsar area (Figure 1). Bharsar is situated about $57 \mathrm{~km}$ from the district headquarter, Pauri Garhwal on the Pauri- Thalisain-Ram Nagar National Highway 121. The district Pauri Garhwal is the most fascinating segment of the Himalaya, stretching from the Ram Ganga River that separates Pauri-Kumaon border in the East and to Ganga demarcating the Western border.

\section{Soil}

Soil texture, color, and nature represent wide range of variations, depending upon geology, altitude, slope aspects, climate, vegetation, and biological and chemical interactions of particular site. In general, the soil is deep clay-loam. The soil is slightly acidic and rich in potassium, medium in phosphorous and nitrogen contents, with the exception of some cultivated fields. 


\section{Climate}

In general, the climate of Bharsar represents mild summer, higher precipitation, and prolonged cold winter season. The climatic factors, such as precipitation, temperature, relative humidity and wind, in association with elevation, slope aspects, drainage, vegetation, etc., are responsible for the micro-climate of this area. Generally, days in Bharsar are fairly warm followed by cool nights. The area receives adequate sunshine hours whereas the growing period is shorter due to long winter. The area also receives heavy precipitation during monsoon and occasional snowfall during winter season. The mean monthly weather data for one year is presented in Figure 2.

\section{Data collection}

The present investigation was a result of extensive and intensive field surveys, conducted from November 2013 to April 2016 and focused on an assessment of angiosperm diversity at the Bharsar and its adjoining areas of Pauri Garhwal. The specimens were collected by usual methods of collection, preservation, and maintenance of specimen in the herbarium with field notes of the collected specimens were identified with the help of recent and relevant floras i.e. Gaur (1999), Naithani (1985).
Information on medicinal properties of various plant species was gathered through personnel interviews with the local inhabitants and also cross-checked with various literature. Usually, the information was collected from the local 'vaidyas' or medicinal practitioners, however occasionally the information was also obtained from housewives, rural old folk, and grazers with long experience.

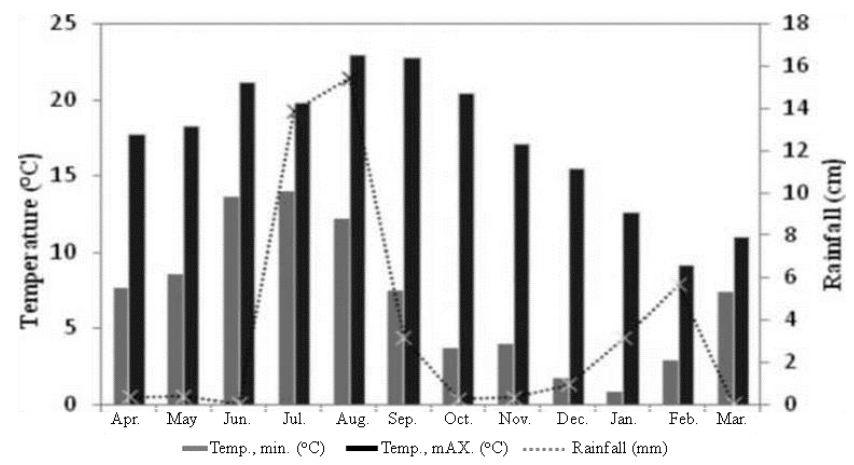

Figure 2. Temperature and rainfall in Bharsar, District of Pauri Garhwal, Uttarakhand, India

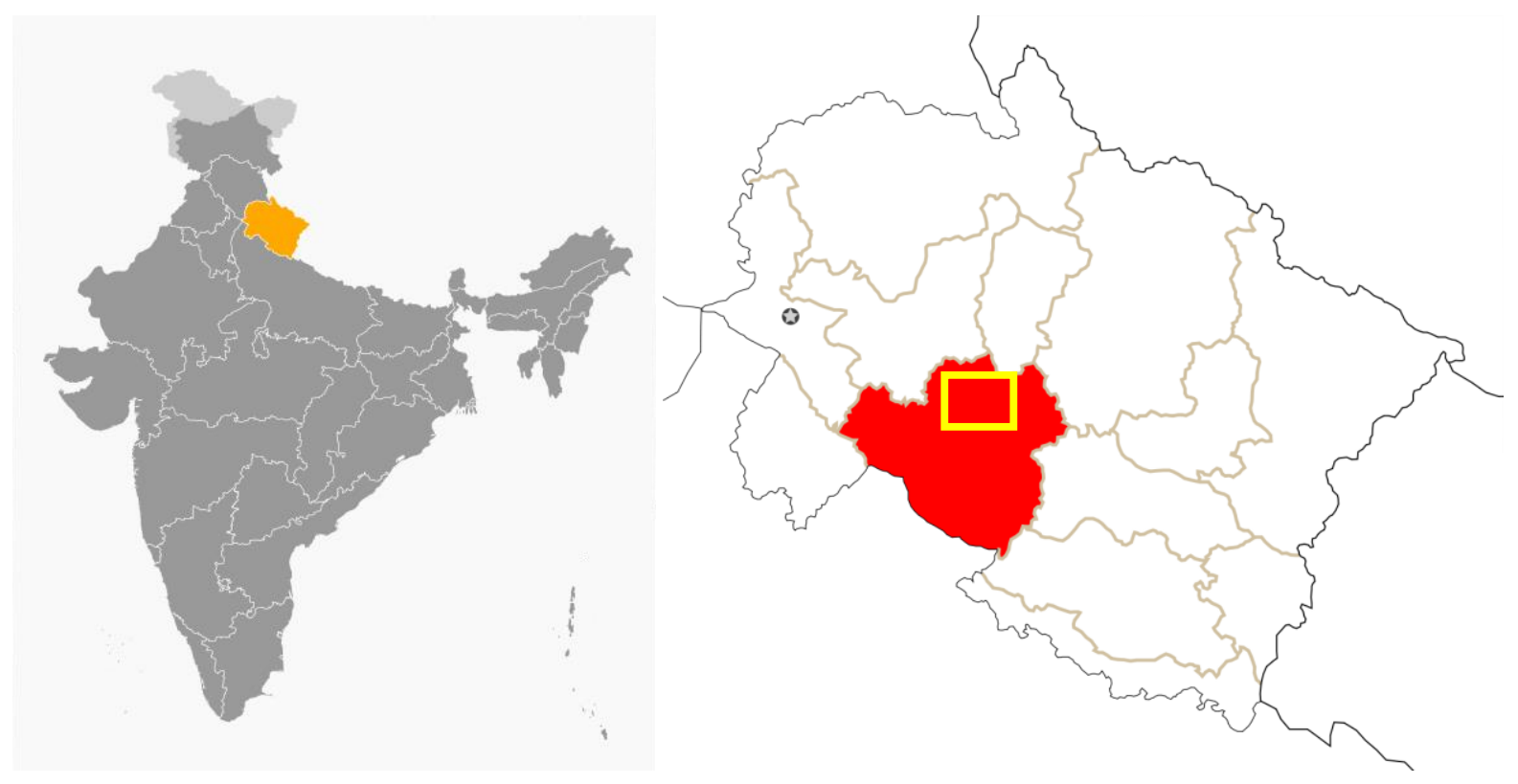

Figure 1. Study site in Bharsar, District of Pauri Garhwal, Uttarakhand, India

Table 1. The summary of families, genera and species of Angiosperms in Bharsar, District of Pauri Garhwal, Uttarakhand, India

\begin{tabular}{lcccccc}
\hline \multirow{2}{*}{ Groups } & \multicolumn{2}{c}{ Families } & \multicolumn{2}{c}{ Genera } & \multicolumn{2}{c}{ Species } \\
\cline { 2 - 7 } & Number & Percent & Number & Percent & Number & Percent \\
\hline Dicotyledones & 66 & 88.00 & 177 & 84.43 & 237 & 86.59 \\
Monocotyledons & 9 & 12.00 & 33 & 15.56 & 37 & 13.40 \\
Total & 75 & 100.0 & 212 & 100.00 & 274 & 100.00 \\
\hline
\end{tabular}




\section{RESULTS AND DISCUSSION}

\section{Results}

In total, 274 species of 75 families of Angiosperm flora were collected during the study period in which 237 species were dicotyledons (66 families) and 37 species of monocotyledons (9 families). Out of the 75 families, Asteraceae contributed the highest share of $13.04 \%$ (36 species), followed by Fabaceae $6.16 \%$ (17 species), Lamiaceae and Rosaceae both $5.43 \%$ (15 species), Poaceae $4.71 \%$, Ranunculaceae $4.35 \%$ (12 species), Polygonaceae $4.04 \%$ (11 species) and other families make $56.84 \%$ of total flora in study area during study period. The composition based on plant habitus is shown in Figure 3 and detailed statistics are presented in Tables 2 and 3 .

The families were arranged according to the Cronquist system of classification (1981). The genera and species were arranged alphabetically. Ethnobotanical uses have also appended wherever applicable those plants are medicinally used.

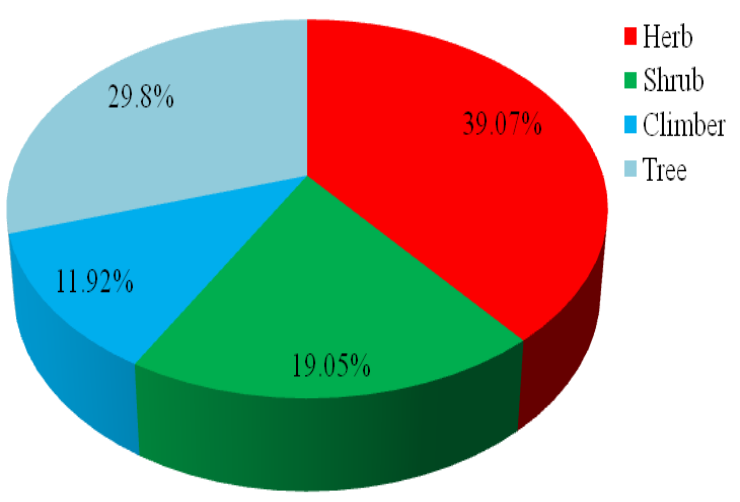

Figure 3. Composition of Angiosperm flora in study area in Bharsar, District of Pauri Garhwal, Uttarakhand, India based on habitus

Table 2. Contribution of family, genera, and species in study area in Bharsar, District of Pauri Garhwal, Uttarakhand, India

\begin{tabular}{lcccc}
\hline \multicolumn{1}{c}{ Family } & \multicolumn{2}{c}{ Genera } & \multicolumn{2}{c}{ Species } \\
& Number & Percent & Number & Percent \\
\hline Acanthaceae & 4 & 1.91 & 4 & 1.46 \\
Amaranthaceae & 3 & 1.44 & 3 & 1.10 \\
Amaryllidaceae & 1 & 0.48 & 1 & 0.37 \\
Anacardiaceae & 2 & 0.96 & 2 & 0.73 \\
Apiaceae & 4 & 1.91 & 4 & 1.46 \\
Apocynaceae & 1 & 0.48 & 1 & 0.37 \\
Araceae & 2 & 0.96 & 2 & 0.73 \\
Araliaceae & 1 & 0.48 & 1 & 0.37 \\
Asteraceae & 26 & 12.38 & 36 & 13.14 \\
Balsaminaceae & 1 & 0.48 & 1 & 0.37 \\
Begoniaceae & 1 & 0.48 & 1 & 0.37 \\
Berberidaceae & 1 & 0.48 & 2 & 0.73 \\
Betulaceae & 1 & 0.48 & 1 & 0.37 \\
Brassicaceae & 3 & 1.44 & 3 & 1.10 \\
\hline
\end{tabular}

\begin{tabular}{|c|c|c|c|c|}
\hline Cannabinaceae & 1 & 0.48 & 1 & 0.37 \\
\hline Caryophyllaceae & 3 & 1.44 & 4 & 1.46 \\
\hline Ceasalpiniaceae & 1 & 0.48 & 1 & 0.37 \\
\hline Chenopodiaceae & 1 & 0.48 & 1 & 0.37 \\
\hline Campanulaceae & 2 & 0.96 & 2 & 0.73 \\
\hline Convolvulaceae & 1 & 0.48 & 1 & 0.37 \\
\hline Corylaceae & 1 & 0.48 & 1 & 0.37 \\
\hline Crassulaceae & 2 & 0.96 & 2 & 0.73 \\
\hline Cucurbitaceae & 4 & 1.91 & 4 & 1.46 \\
\hline Cyperaceae & 4 & 1.91 & 6 & 2.19 \\
\hline Daphniphylaceae & 1 & 0.48 & 1 & 0.37 \\
\hline Dioscoreaceae & 1 & 0.48 & 2 & 0.73 \\
\hline Dipsacaceae & 1 & 0.48 & 1 & 0.37 \\
\hline Ericaceae & 5 & 2.38 & 3 & 1.10 \\
\hline Euphorbiaceae & 3 & 1.43 & 3 & 1.10 \\
\hline Fabaceae & 12 & 5.72 & 17 & 6.21 \\
\hline Fagaceae & 1 & 0.48 & 4 & 1.46 \\
\hline Fumariaceae & 1 & 0.48 & 2 & 0.73 \\
\hline Gentianaceae & 3 & 1.43 & 8 & 2.92 \\
\hline Geraniaceae & 1 & 0.48 & 2 & 0.73 \\
\hline Hippocastanaceae & 1 & 0.48 & 1 & 0.37 \\
\hline Hypericaceae & 1 & 0.48 & 3 & 1.10 \\
\hline Juglandaceae & 1 & 0.48 & 1 & 0.37 \\
\hline Lamiaceae & 13 & 6.19 & 15 & 5.48 \\
\hline Lauraceae & 3 & 1.44 & 4 & 1.46 \\
\hline Liliaceae & 3 & 1.43 & 3 & 1.10 \\
\hline Linaceae & 1 & 0.48 & 1 & 0.37 \\
\hline Lythraceae & 1 & 0.48 & 1 & 0.37 \\
\hline Malvaceae & 1 & 0.48 & 1 & 0.37 \\
\hline Meliaceae & 2 & 0.96 & 2 & 0.73 \\
\hline Mimosaceae & 1 & 0.48 & 1 & 0.37 \\
\hline Moraceae & 1 & 0.48 & 5 & 1.83 \\
\hline Myricaceae & 1 & 0.48 & 1 & 0.37 \\
\hline Orchidaceae & 6 & 2.86 & 6 & 2.19 \\
\hline Oxalidaceae & 1 & 0.48 & 2 & 0.73 \\
\hline Papaveraceae & 1 & 0.48 & 1 & 0.37 \\
\hline Plantaginaceae & 1 & 0.48 & 2 & 0.73 \\
\hline Poaceae & 12 & 5.72 & 13 & 4.75 \\
\hline Polygonaceae & 7 & 3.34 & 11 & 4.02 \\
\hline Primulaceae & 2 & 0.96 & 2 & 0.73 \\
\hline Ranunculaceae & 4 & 1.91 & 12 & 4.38 \\
\hline Rhamnaceae & 1 & 0.48 & 1 & 0.37 \\
\hline Rosaceae & 11 & 5.24 & 15 & 5.48 \\
\hline Rubiaceae & 3 & 1.43 & 6 & 2.19 \\
\hline Rutaceae & 3 & 1.43 & 3 & 1.10 \\
\hline Sapotaceae & 1 & 0.48 & 1 & 0.37 \\
\hline Saxifragaceae & 4 & 1.91 & 4 & 1.46 \\
\hline Scrophulariaceae & 6 & 2.86 & 6 & 2.19 \\
\hline Smilacaceae & 2 & 0.96 & 2 & 0.73 \\
\hline Solanaceae & 1 & 0.48 & 2 & 0.73 \\
\hline Symplocaceae & 1 & 0.48 & 1 & 0.37 \\
\hline Theaceae & 1 & 0.48 & 1 & 0.37 \\
\hline Thymelaeaceae & 1 & 0.48 & 1 & 0.37 \\
\hline Tiliaceae & 2 & 0.96 & 2 & 0.73 \\
\hline Ulmaceae & 1 & 0.48 & 2 & 0.73 \\
\hline Urticaceae & 3 & 1.44 & 3 & 1.10 \\
\hline Valerianaceae & 1 & 0.48 & 2 & 0.73 \\
\hline Verbenaceae & 2 & 0.96 & 2 & 0.73 \\
\hline Violaceae & 1 & 0.48 & 3 & 1.10 \\
\hline Vitaceae & 1 & 0.48 & 1 & 0.37 \\
\hline Zingiberaceae & 2 & 0.96 & 2 & 0.73 \\
\hline Total & 210 & 100 & 274 & 100 \\
\hline
\end{tabular}


Table 3. List of taxa with ethnobotany notes in Bharsar, District of Pauri Garhwal, Uttarakhand, India

\begin{tabular}{|c|c|c|c|}
\hline Botanical name & Local name & Habit & Ethnobotany \\
\hline \multicolumn{4}{|l|}{ DICOTYLEDINEAE } \\
\hline \multicolumn{4}{|l|}{ Lauraceae } \\
\hline Cinnamomum tamala Buch. - Ham. & $\begin{array}{l}\text { Dalchini, } \\
\text { Tejpat. }\end{array}$ & Tree & Bark and dried leaves are used for flavoring tea and various food preparations; bark is chewed for dyspepsia and throat irritation \\
\hline $\begin{array}{l}\text { Neolitsea cuipala } \text { Buch. - Ham. ex } \\
\text { D.Don. }\end{array}$ & Lampatiya & Tree & $\begin{array}{l}\text { Twigs are used as fuel and leaves as fodder. Fruits paste with Camphor are applied on infested wounds of cattle. Wood is used for } \\
\text { agricultural implements. }\end{array}$ \\
\hline Neolitsea pallens D. Don. & Bilaru & Tree & Wood is used for construction of various articles. Oil extract from the fruits is used in scabies and eczema. \\
\hline Persea odoratissima (Nees) & Kaula & Tree & Wood is for construction and furniture; plants are used for silkworm farming. \\
\hline \multicolumn{4}{|l|}{ Ranunculaceae } \\
\hline Anemone obtusiloba D. Don. & Kanchphool & Herb & Root decoction is given to cure diarrhea. \\
\hline Anemone rivularis Buch $-\mathrm{Ham}$. & Mirchilee & Herb & Paste of leaves is applied externally on forehead in headache. Leaf juice is applied to wound, sores, and earache in local therapy. \\
\hline Anemone vitifolia Buch.-Ham. ex DC. & Mudeela & Herb & Roots and leaves paste are applied externally on ringworm and eczema in folk medicine and leaves used as fodder \\
\hline Clematis barbellata Edgew. & Kanguli & Climber & Leaves are poisonous to cattle, leaf paste is externally applied for skin ailments. \\
\hline Clematis gouriana Roxb. ex DC. & Kanguli & Climber & $\begin{array}{l}\text { Leaves are poisonous to livestock, fiber is used for coarse ropes. The root decoction (about } 15 \mathrm{ml} \text { ) is used three times every day for } \\
\text { three days in stomachache. }\end{array}$ \\
\hline Clematis connata DC. & Ghantiyali & Climber & Leaves are used as fodder for goat and sheep. \\
\hline Clematis montana Buch.-Ham. ex DC. & Kujju. & Climber & Leaves are browsed by sheep and goats. Leaf extract is given to cure diabetes and urinary troubles \\
\hline Ranunculus diffusus DC. & $\begin{array}{l}\text { Angasia - } \\
\text { Jhar. }\end{array}$ & Herb & - \\
\hline Rannunculus hirtellus Royle & Simariya & Herb & Plant paste is externally used on deteriorated wounds. Plant is browsed by goats. \\
\hline $\begin{array}{l}\text { Ranunculus laetus Wallich ex D.Don. } \\
\text { in Royle }\end{array}$ & Dainya & Herb & \\
\hline Thalictrum foliolosum DC. & Mamiri & Herb & Root is used in ophthalmia and also in colic and fever. \\
\hline Thalictrum secundum Edgew. & Peelijari & Herb & Root is juice taken to relieve stomach disorders in folk medicine. \\
\hline \multicolumn{4}{|l|}{ Berberidaceae } \\
\hline Berberis aristata DC. & Kingore & Shrub & $\begin{array}{l}\text { Juice from bark of stem or root often known as 'Rasaut' dropped in ophthalmia. Infusion of root is given in fever. Edible fruits, bark } \\
\text { yields yellow dye. }\end{array}$ \\
\hline Berberis asiatica Roxb. ex DC. & Kilmora & Shrub & Root decoction (about $20 \mathrm{ml}$.) is taken thrice a day in body inflammation and stomachache. \\
\hline Papaveraceae & & & \\
\hline Argemone mexicana Linn & Kanjilu & Herb & The seed emetic and narcotic are used as medicine; root decoction as wormicide; root chewed in leucorrhoea. \\
\hline \multicolumn{4}{|r|}{ 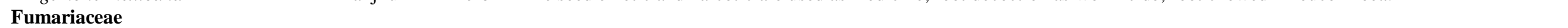 } \\
\hline Corydalis cashmeriana Royle & - & Herb & - \\
\hline Corydalis cornuta Royle & Balsam jar & Herb & Aqueous paste of roots taken to reduce body swelling and inflammations root juice given in fever. \\
\hline $\begin{array}{l}\text { Daphniphylaceae } \\
\text { Daphniphyllum himalense Benth. }\end{array}$ & Ratniyalu & Tree & Wood is used in agriculture implements and fuel. \\
\hline
\end{tabular}




\begin{tabular}{|c|c|c|c|}
\hline \multicolumn{4}{|l|}{ Ulmaceae } \\
\hline Celtis australis Linn. & Kharik & Tree & $\begin{array}{l}\text { Edible fruits, leaves provide good fodder. Bark gives yellow dye, wood used for making small articles. It is an important tree of } \\
\text { agroforestry. }\end{array}$ \\
\hline Celtis eriocarpa Decne. in Jacq. & Kharik & Tree & Edible fruits, leaves as fodder, wood for fuel and making small articles, etc. \\
\hline \multicolumn{4}{|l|}{ Cannabinaceae } \\
\hline Cannabis sativa Linn. & Bhang & Herb & $\begin{array}{l}\text { Bark - fiber used for making ropes, sacs, and rough clothes; stem as a fuel. Seed is used as condiment; seed - oil edible, besides, } \\
\text { its leaves and flowers used as an intoxicating agent }\end{array}$ \\
\hline \multicolumn{4}{|l|}{ Moraceae } \\
\hline Ficus auriculata Lour. & Timla & Tree & $\begin{array}{l}\text { Leaves are made into cups and plates; also provide good fodder for cattle; ripe fruit edible, unripe fruits made into vegetables. } \\
\text { Plants are conserved for their religious significance and utilisations. }\end{array}$ \\
\hline Ficus palmata Forsk. & Bedu & Tree & $\begin{array}{l}\text { Leaves and twigs yield good fodder, fruits delicious in taste, often taken with salt or filled inside the bread, fruits medicinal for } \\
\text { digestive disorders and useful plant of Agroforestry. }\end{array}$ \\
\hline Ficus sarmentosa Buch. - Ham & Beduli & Shrub & Edible fruits; leaves provide good fodder. \\
\hline Ficus subincisa Buch. - Ham. & Chachari & Tree & Leaves and branches are used as fodder; Edible fruits \\
\hline Ficus religiosa Linn. & Peepal & Tree & Traditional use as in Temples and as fodder. \\
\hline \multicolumn{4}{|l|}{ Urticaceae } \\
\hline Urtica dioica Linn. & Kandali & Shrub & $\begin{array}{l}\text { Stem yield strong - shining fiber, used for sacs, ropes, and mass; young branches and leaves are used as delicious pot herb; seed oil } \\
\text { edible as well as medicine in sciatica, rheumatism and several skin ailments; hair - wash leaf extract believed to avoid baldness. }\end{array}$ \\
\hline Elatostema sessile J. \& G.Forster & Chaulu. & Herb & - \\
\hline $\begin{array}{l}\text { Girardinia diversifolia (Link.) Friis, } \\
\text { Kew Bull. }\end{array}$ & $\begin{array}{l}\text { Bhainsya } \\
\text { kandali }\end{array}$ & Herb & - \\
\hline \multicolumn{4}{|l|}{ Juglandaceae } \\
\hline Juglans regia Linn. & Akhrot & Tree & $\begin{array}{l}\text { Edible fruits and also provide oil, wood is hard, excellent for furniture, carved work, gunstocks, and veneers. Bark used as dye and } \\
\text { as medicine, rind of fruits used to intoxicate fishes and for dyeing and tanning. Leaves mixed with stored grains as fungicide and } \\
\text { insecticide and important tree of social forestry. }\end{array}$ \\
\hline \multicolumn{4}{|l|}{ Myricaceae } \\
\hline $\begin{array}{l}\text { Myrica esculanta Buch.-Ham. ex } \\
\text { D.Don. }\end{array}$ & Kaphal & Tree & $\begin{array}{l}\text { Edible fruits, raw or made into refreshing drinks, bark is used to intoxicate fishes and yield yellow dye and wood is used as fuel } \\
\text { and in agricultural implements. }\end{array}$ \\
\hline \multicolumn{4}{|l|}{ Betulaceae } \\
\hline Alnus nepalensis D.Don. & Utees & Tree & Wood is used for carpentry and construction; bark used is in local medicine; fast-growing trees used as soil binders. \\
\hline \multicolumn{4}{|r|}{ 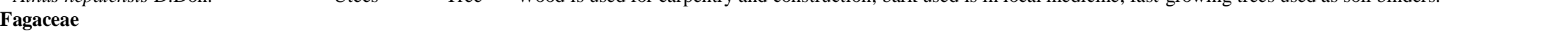 } \\
\hline $\begin{array}{l}\text { Quercus floribunda Lindley ex } \\
\text { Rehder. }\end{array}$ & $\begin{array}{l}\text { Moru or } \\
\text { Tilonj, }\end{array}$ & Tree & Wood is used as household articles and as fuel, leaves provide fodder, fruits eaten by wild animals. \\
\hline Quercus glauca Thunb. & $\begin{array}{l}\text { Harinj, } \\
\text { Phaniyant }\end{array}$ & Tree & Wood is used as household articles and as fuel, leaves provide fodder. \\
\hline $\begin{array}{l}\text { Quercus leucotrichophora A. Camus } \\
\text { in Riviera Sci. }\end{array}$ & $\begin{array}{l}\text { Banj, Eng. } \\
\text { White Oak. }\end{array}$ & Tree & $\begin{array}{l}\text { Wood is used as fuel, rarely for agricultural implements; leaves as fodder. Leaves are used as fodder, gum of the tree medicinally is } \\
\text { used for gonorrheal and digestive disorders. Fruits are eaten by monkeys and bears decomposed leaves used, as organic manure. It } \\
\text { is also an important tree of social forestry. }\end{array}$ \\
\hline Quercus semecarpifolia Smith & $\begin{array}{l}\text { Khairu or } \\
\text { Kharsu }\end{array}$ & Tree & Wood is used as fuel, rarely for agricultural implements; leaves as fodder, important tree for social forestry. \\
\hline \multicolumn{4}{|l|}{ Corylaceae } \\
\hline Carpinus viminea Lindley & $\begin{array}{l}\text { Kathway, } \\
\text { Chamkharik }\end{array}$ & Tree & Wood is used for furniture and articles of sports as well as weaving shuttle; leaves used as fodder. \\
\hline \multicolumn{4}{|l|}{ Chenopodiaceae } \\
\hline Chenopodium album Linn & Bathua & Herb & Leaves is used as pot- vegetable; bread prepared from the grinned grains. \\
\hline
\end{tabular}




\begin{tabular}{|c|c|c|c|}
\hline \multicolumn{4}{|l|}{ Amaranthaceae } \\
\hline Achyranthes bidentata Blume & $\begin{array}{l}\text { Chicheree, } \\
\text { Latjira }\end{array}$ & Herbs & $\begin{array}{l}\text { Root infusion is taken in malarial fever. Leaf extract supposed to facilitate delivery, root powder used in making local beverages, } \\
\text { plant decoction used in dropsy and bronchitis. }\end{array}$ \\
\hline $\begin{array}{l}\text { Alternanthera sessilis (Linn.) DC. in } \\
\text { Cat. }\end{array}$ & Gudre-Saag & Herb & Occasionally leaves are used as vegetables during scarcity. \\
\hline $\begin{array}{l}\text { Cyathula tomentosa (Roth) Moq. in } \\
\text { DC. }\end{array}$ & Lichkura & Herb & Leaf extract has emetic properties and given in snakebite, plant used as fodder. \\
\hline \multicolumn{4}{|l|}{ Caryophyllaceae } \\
\hline Arenaria serpyllifolia Linn. & & Herb & \\
\hline Stellaria media (Linn.)Vill. & Badyal & Herb & Plant is used as green vegetables, as well as fodder; plant paste is externally applied on burns, boils, and wounds. \\
\hline Stellaria monosperma Buch. - Ham. & Badyalu & Herb & \\
\hline Gypsophila cerastioides D.Don. & Bakarchee & Herb & Poultice of plant applied on boils and wounds. \\
\hline \multicolumn{4}{|l|}{ Polygonaceae } \\
\hline Bistorta amplexicaul D.Don. & Kutrya & Herb & Decoction of plant is said to cause abortion if taken orally. Leaf paste is applied on wounds and extracted to relive dysentery \\
\hline $\begin{array}{l}\text { Fagopyrum dibotrys Wallich ex } \\
\text { Meisn. }\end{array}$ & Kanalya & Herb & Leaves occasionally are used as vegetables and leaf paste rubbed on insect bites. \\
\hline Fallopia pterocarpa Wall. & - & Herb & - \\
\hline Koenigia delicatula (Meisn) Hara. & - & Herb & - \\
\hline Persicaria barbata (Linn.) Hara. & - & Herb & - \\
\hline $\begin{array}{l}\text { Persicaria capitata (Buch.-Ham. ex } \\
\text { D.Don) }\end{array}$ & Kaflya & Herb & - \\
\hline Polygonum emodi Meissn. & - & Herb & - \\
\hline Polygonum plebeium $\mathrm{R}$. Br. & Dondya & Herb & Plant is used for manure and root extract is applied on head to avoid baldness. \\
\hline Polygonum recumbens. Royle & - & Herb & \\
\hline Rumex hastatus D.Don. & Almoru & Herb & $\begin{array}{l}\text { Sour leaves, made into sauce, leaf extract applied on cuts and wounds to check bleeding and also believed to relieve nettle sting } \\
\text { inflammation. }\end{array}$ \\
\hline Rumex nepalensis Spreng. & Almora & Herb & The sap of leaves and stems is applied on cuts for its astringent powder. \\
\hline \multicolumn{4}{|l|}{ Theaceae } \\
\hline Eurya acuminata DC & Deura & Tree & Wood is used as fuel and for agricultural implements. Green leaves and young twigs are lopped for fodder. \\
\hline \multicolumn{4}{|r|}{ 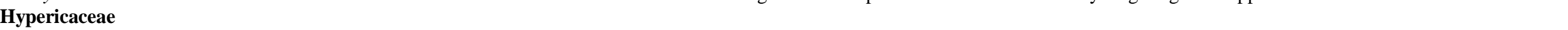 } \\
\hline Hypericum elodeoides Choisy in DC. & Basanti. & Herb & - \\
\hline Hypericum oblongifolium Choisy & Chitroi & Herb & Leaves are lopped for fodder, roots yield yellow dye, decoction of leaves and stem given to facilitate delivery \\
\hline Hypericum uralum Linn. & Bhyoul & Herb & $\begin{array}{l}\text { Paste of leaves is applied on cuts to stop bleeding. Infusion of leaf given in malarial fever. Seed powder against food poisoning and } \\
\text { as abortifacient. }\end{array}$ \\
\hline \multicolumn{4}{|l|}{ Tiliaceae } \\
\hline Grewia sapida Roxb. ex DC. & Bhimal & Shrub & The extraction of bark is given to pregnant women for smooth delivery. The extraction is also given in constipation. \\
\hline Triumfetta rhomboidea Jacq. & Liswa Kura & Shrub & Root juice is applied on the cuts; hot infection of fruits and leaves is given to facilitate delivery. \\
\hline \multicolumn{4}{|l|}{ Malvaceae } \\
\hline \multirow{2}{*}{\multicolumn{4}{|c|}{ 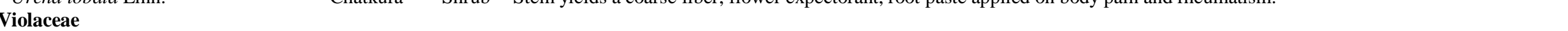 }} \\
\hline & & & \\
\hline Viola biflora J. Smith in Rees. & Banfsa & Herb & $\begin{array}{l}\text { The whole plant either in the form of extract or powder is taken as diaphoretic, useful in skin and blood diseases, flowers and } \\
\text { leaves boiled with tea, supposed to be good for fever and cough. }\end{array}$ \\
\hline Viola tricolor Wallich in Roxb & Banfsa & Herb & $\begin{array}{l}\text { Decoction of plants is useful in malarial fever, bronchitis and asthma, root used as an emetic, flower demulcent, sometimes eaten } \\
\text { raw and leaf juice applied on cuts and wounds. }\end{array}$ \\
\hline Viola pilosa Blume & Banafsa. & Herb & Fresh flower is boiled with tea to relieve cough and cold. Flowers are eaten raw: leaf paste applied on headache and jaundice. \\
\hline
\end{tabular}




\section{Cucurbitaceae}

Coccinia grandis (Linn.) Voigt.

Cucumis hardwickii Royle.

Mukia maderaspatana Linn.

Solena amplexicaulis Lam.

\section{Begoniaceae}

Begonia picta Smith

Brassicaceae

Barbarea vulgaris R.Br. in Aiton f.

Rorippa indica (Linn.) Hiern.

Thlaspi arvense Linn.

\section{Ericaceae}

Gaultheria nummularioides D.Don. Lyonia ovalifolia (Wallich) Drude.

Rhododendron arboreum Smith.

\section{Sapotaceae}

Madhuca longifolia Koeing Mahwa

Symplocaceae

Symplocos ramosissima Walich

G.Don.

\section{Primulaceae}

Androsace lanuginosa Wallich in

Roxb.

Primula denticulata Smith

\section{Crassulaceae}

Sedum rosulatum Edgew.

\section{Saxifragaceae}

Astilbe rivularis. Buch. - Ham.

Bergenia ciliata (Har) Sternb

Parnassia nubicola Wallich ex Royle.

Saxifraga diversifolia Wallich ex

Seringe in DC.

\section{Rosaceae}

Agrimonia pilosa Ledebour in Index

Sem.

Cotoneaster microphyllus Wallich ex Lindley in Edgew.

Gawal
Kaduri Herb Leaves and root juice are given in diabetes, leaves are also supposed to be antiseptic; fruit juice is given in gonorrhea.

Elaroo Herb Decoction of root barks is given and fevers; seeds are given in suppressed urination.

Ban kakari Climber Fruit and vegetable are given in malarial fever and urinary disorders; seed paste with warm is water given to relieve vomiting.

Herb Root and seed are given in digestive troubles; seed mixed with leaf extract of Vasik, believed to cause abortion.

Patharchatta Herb Decoction of plant in boiled is water given in colic and dyspepsia and young leaves occasionally cooked as vegetable.

Piria Herb Plant juice is given in diarrhea and pastes applied on sprains.

Maula, Herb Leaves are used as green vegetables; poultice of leaves applied on cuts and wounds

Bhwinla Shrub -

Anyar Tree Wood is used as fuel, young leaves poisonous to cattle, and seed paste applied on wounds and boils.

Burans Tree Wood is used for fuel and charcoal, flowers eaten raw or made into sauce, jellies, jams or refreshing drinks, flowers and bark medicinally for digestive and respiratory disorders, and flowers useful in bee forage.

Tree Wood for various constructions flowers and Edible fruits, afresh or made into several preparations; useful in apiculture as bee forage; seeds yield an oil, used for candle and soap manufacturing; flowers often used in local beverages.

Tree Leaves are used a fodder; flowers visited by bees for nectar and pollen

Herb

Jalkutra, Eng. Herb Aqueous paste of flowers is used in the treatment of diabetes and urinary ailments and root paste applied to kill lice.

Primrose

Herb

Shrub Traditionally is used in workshop of deities. Powder is believed to be an abortifacient, leaves used as fodder.

Silpari, Herb The leaves and roots of plants are given to the patient of kidney stone. The folk belief is that if the patient takes it thrice a day i.e. Pasanbhed. morning, noon, evening he will get rid of stone very soon.

Herb Plant extract is taken to stimulate vomiting in case of food poisoning, paste from rootstock applied externally as an antidote to snakebite.

Silyans. Herb Root extract is used as vermifuge

Lesukuria Herb Plant decoction is given in cough and diarrhea, root paste with mustard oil is applied around the belly in suppressed urination.

Bugarchilla Shrub Branches are used for making baskets, ripe fruit edible, and fuel from wood. Leaf extract and fruits are given in diarrhea, root paste is applied on cuts and wounds and flowers useful in apiculture. 


\begin{tabular}{|c|c|c|c|}
\hline $\begin{array}{l}\text { Fragaria nubicola Lindley ex Lacaita } \\
\text { in J. Linn. Soc. Bot. }\end{array}$ & Gand-kaphal & Herb & Edible fruits, leaf juice is dropped for relieving earache and fruits are also used in local beverages. \\
\hline Potentilla atrosanguinea Lod. & - & Herb & - \\
\hline Potentilla fulgens Wallich ex Hook. & $\begin{array}{l}\text { Bajardantu, } \\
\text { Bajradanti }\end{array}$ & Herb & The paste of root is used for healing wounds. Edible fruits, plant juice applied to mouth in stomatitis and aphthae. \\
\hline Potentilla gerardiana Lindl. ex Lehm. & - & Herb & Root paste is applied to wounds. \\
\hline Potentilla nepalensis Hook. & - & Herb & - \\
\hline Prinsepia utilis Royle & Bhainkal & Shrub & $\begin{array}{l}\text { Seeds yield oil, used for edible purposes as well as medicinal in rheumatic pains. Root bark is used in diarrhea, flowers useful in } \\
\text { apiculture as bee forage and sometimes plant used as biofence. }\end{array}$ \\
\hline Prunus cerasoides D.Don. & Panyyan & Tree & $\begin{array}{l}\text { Branches for walking sticks, bark in psych medicines, leaves as fodder and ripe Edible fruits, and the juice from the bark applied } \\
\text { on body swelling and contusion, flower useful source of bee forage. Plant regarded as sacred, used in several rituals of locals. }\end{array}$ \\
\hline $\begin{array}{l}\text { Pyracantha crenulata (D.Don) M. } \\
\text { Roemer. }\end{array}$ & Ghingaru & Shrub & $\begin{array}{l}\text { Branches are used for walking sticks and tool handles, fruits are rarely edible, flowers are useful in apiculture as bee forage and } \\
\text { plants act as soil binder. }\end{array}$ \\
\hline Pyrus pashia Buch.-Ham. ex D.Don. & $\begin{array}{l}\text { Malu or } \\
\text { Mahel }\end{array}$ & Tree & $\begin{array}{l}\text { Leaves and twig as fodder. Ripe Edible fruits are used in digestive disorders; wood made in to stick; flower use fuel in apiculture; } \\
\text { believed to check soil erosion in landslide zones. }\end{array}$ \\
\hline Rosa brunonii Lindley. & Kunja, Kujju & Shrub & $\begin{array}{l}\text { Edible fruits, wood is used as an occasional fuel, flowers is useful in apiculture as bee forage and flower paste is applied on skin } \\
\text { ailments. }\end{array}$ \\
\hline Rubus ellipticus Smith in Rees. & $\begin{array}{l}\text { Hinssar, } \\
\text { Hisolu }\end{array}$ & Shrub & $\begin{array}{l}\text { Edible fruits, root extract is used in local beverages as intoxicating ingredient, flowers are useful in apiculture as bee forage and } \\
\text { plant act as soil binders. }\end{array}$ \\
\hline Rubus foliosus D.Don. & Kala Hissar & Shrub & Young twigs and Edible fruits. \\
\hline Rubus paniculatus. Smith & Kathula & Shrub & Fruit is edible; leaf paste is externally applied on skin ailments. \\
\hline Spiraea bella Sims in Curtis & Kuji. & Shrub & Branches are used as brooms, seed paste applied to wash sores and wounds. \\
\hline Mimosaceae & & & \\
\hline $\begin{array}{l}\text { Acacia dealbata Link. } \\
\text { Caesalpiniaceae }\end{array}$ & Chikaka & Tree & - \\
\hline $\begin{array}{l}\text { Caesalpiniaceae } \\
\text { Caesalpinia decapetala Roth. }\end{array}$ & Kingri & Shrub & Leaves are used as fodder of goat and sheen : leaves anplied to burns: bark vield tannin flowers useful of bee- forages. \\
\hline Fabaceae & N & N & 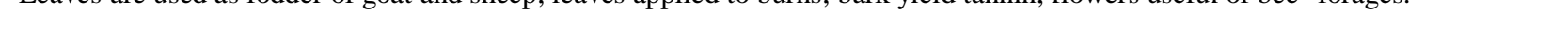 \\
\hline $\begin{array}{l}\text { Astragalus leucocephalus Graham ex } \\
\text { Benth. in Royle }\end{array}$ & Rudravanti & Herb & Roots are used as blood purifiers and in skin diseases; plant infusion as tonic, leaves used as fodder. \\
\hline Crotalaria albida Heyne ex Roth & Chunchuni & Herb & Roasted seed powder is taken as blood purifier and roots chewed in constipation. \\
\hline Crotolaria medicaginea Lam. & Ban-Methi & Herb & Leaf juice is applied in scabies and urticaria. \\
\hline Desmodium concinnum DC. & Sakina & Herb & - \\
\hline $\begin{array}{l}\text { Desmodium microphyllum (Thunb.) } \\
\text { DC. }\end{array}$ & - & Shrub & - \\
\hline Desmodium multiflorum DC. & - & Herb & Plants are browsed by cattle. \\
\hline Dumasia villosa DC. & - & Herb & - \\
\hline Eriosema himalaicum Ohashi. & Bhatiya & Shrub & The tuberous root is edible. \\
\hline Erythrina arborescens Roxb & - & Tree & $\begin{array}{l}\text { Leaflets are used for making plates and cups; bark is used in skin diseases; leaf extract is given in suppressed menses, and also for } \\
\text { intestinal worms; an important tree of social forestry. }\end{array}$ \\
\hline Erythrina suberosa Roxb. & Manura. & Tree & Wood soft, used for minor articles barks as an insecticide; leaf extracts in gonorrheal diseases. An important tree of social forestry \\
\hline $\begin{array}{l}\text { Flemingia strobilifera (Linn.) R.Br. in } \\
\text { Aiton f. }\end{array}$ & Bari-Kapasi & Shrub & Plants are used as brooms. Leaves for treating hysteria and also used as fodder \\
\hline Indigofera glandulosa Willd. & & Herb & \\
\hline $\begin{array}{l}\text { Indigofera heterantha Wallich ex } \\
\text { Brandis }\end{array}$ & Sakina & Shrub & $\begin{array}{l}\text { Flowers are used as vegetable, leaves are lopped for fodder, twigs are made into baskets or containers. Leaf juice is taken in } \\
\text { diarrhea, dysentery, and cough. }\end{array}$ \\
\hline
\end{tabular}




\begin{tabular}{|c|c|c|c|}
\hline Lathyrus aphaca Linn. & Kurphali & Climbe & As a weed of crop fields and used as fodder. \\
\hline $\begin{array}{l}\text { Piptanthus nepalensis (Hook.) D.Don } \\
\text { in Sweet. }\end{array}$ & Chembera. & Shrub & $\begin{array}{l}\text { Green pods are chewed raw, ripe seeds are cooked as vegetables and extract is used as galactagogue. Leaf juice is dropped in } \\
\text { pussed ear. }\end{array}$ \\
\hline Robinia pseudoacacia Roxb. & Black locust & Tree & It is one of the most important nitrogen-fixing Agroforestry trees. \\
\hline Trifolium repens Linn. & Tpatiya & Herb & Leaf paste is used as an astringent; plant provides good fodder. \\
\hline \multicolumn{4}{|l|}{ Lythraceae } \\
\hline $\begin{array}{l}\text { Woodfordia fruticosa (Linn.) Kurz in } \\
\text { J. Asiat. }\end{array}$ & Dhaula & Shrub & $\begin{array}{l}\text { Flowers yield dye for silk, leaves, and bark medicinal, as febrifuge, dried flower used as tonic particularly in hemorrhoids, flowers } \\
\text { useful in apiculture as bee forage and also made into refreshing drink during summer and also good soil binder. }\end{array}$ \\
\hline \multicolumn{4}{|l|}{ Thymelaeaceae } \\
\hline Daphne papyracea Wallich ex Studel. & $\begin{array}{l}\text { Vern. } \\
\text { Satpura }\end{array}$ & Shrub & $\begin{array}{l}\text { Ropes and sacs made from the stem fiber, in the past paper was manufactured from the stem and leaves, known as Satpura, } \\
\text { especially used for religious purposes and leaf paste applied on eczema }\end{array}$ \\
\hline \multicolumn{4}{|l|}{ Euphorbiaceae } \\
\hline Euphobia royleana Boissier in DC. & Sulla & Shrub & Planted for hedges as well as to check soil erosion in the exposed slopes. Latex considered antiseptic and germicidal. \\
\hline Phyllanthus amarus Schum\& Thonn. & Bumianwala. & Herb & Herb as an astringent stomachache diuretic and febrifuge; leaves are said to bear antibacterial properties. \\
\hline $\begin{array}{l}\text { Sapium insigne (Royle) Benth. ex } \\
\text { Trimen. }\end{array}$ & Khinna & Tree & $\begin{array}{l}\text { Leaves and bark are used for intoxicating fishes, wood is used for making floats, cases, drums, toys, matchboxes, latex is regarded } \\
\text { as poisonous, causes blisters. }\end{array}$ \\
\hline \multicolumn{4}{|l|}{ Rhamnaceae } \\
\hline $\begin{array}{l}\text { Rhamnus purpureus Edgew. in Trans. } \\
\text { Linn. Soc. }\end{array}$ & Gaunta & Shrub & $\begin{array}{l}\text { Wood is used in agricultural implements, leaves are lopped for fodder and manure, flower is useful source of bee forage, barks } \\
\text { extract with milk given in digestive disorders. }\end{array}$ \\
\hline \multicolumn{4}{|l|}{ Vitaceae } \\
\hline $\begin{array}{l}\text { Ampelocissus divaricata Wallichx } \\
\text { Lowson }\end{array}$ & Pan - laguli. & Shrub & Fruits and young leaves are edible; stem as fibers. \\
\hline \multicolumn{4}{|l|}{ Linaceae } \\
\hline Reinwardtia indica Dumortier & Phiunli & Herb & $\begin{array}{l}\text { Petals are chewed as tongue wash, considered sacred, as indicator of spring season and flower useful in apiculture as a source of } \\
\text { bee forage. }\end{array}$ \\
\hline \multicolumn{4}{|l|}{ Hippocastanaceae } \\
\hline $\begin{array}{l}\text { Aesculus indica (Colebr. ex Cambess.) } \\
\text { Hook. in Curtis }\end{array}$ & Pangar & Tree & $\begin{array}{l}\text { Cream-colored wood is made into pots and vessels, fruits are given to cattle and goat, flour from seed mixed with wheat flour } \\
\text { during famine, seed paste is applied in rheumatic pain, flowers are useful in apiculture as a source of bee forage, leaves as fodder } \\
\text { and manure, and also important tree of social forestry. }\end{array}$ \\
\hline \multicolumn{4}{|r|}{. } \\
\hline Cotinus coggygria Scopoli. & Jal-Tungla & Shrub & Bark and leaves are used for tanning, leaves are used for cattle padding and flowers useful sources of bee forage. \\
\hline Rhus parviflora Roxb. & Tungla & Tree & $\begin{array}{l}\text { Edible fruits, leaves mixed with tobacco, sometimes during famine fruits ground and mixed with flour. Infusion of leaves given in } \\
\text { cholera, flowers useful source of bee-forage in apiary and sometimes used as biofence }\end{array}$ \\
\hline \multicolumn{4}{|l|}{ Meliaceae } \\
\hline Melia azadirach Linn. & Dainkan. & Tree & $\begin{array}{l}\text { Leaves fruits and seeds are useful in skin diseases as well as in rheumatic pains. Fruits and leaves as antiseptics, leaves as fodder; } \\
\text { wood useful source of bee - forage in apiary. }\end{array}$ \\
\hline $\begin{array}{l}\text { Toona hexandra (Wallich ex Roxb.) } \\
\text { M. Roemer }\end{array}$ & Tun & Tree & $\begin{array}{l}\text { It is important tree for construction purposes, furniture, and other articles. Sulphur dye is obtained from the flowers, useful source } \\
\text { of bee-forage and apiculture, and also important tree of social forestry. }\end{array}$ \\
\hline \multicolumn{4}{|l|}{ Rutaceae } \\
\hline $\begin{array}{l}\text { Boenninghausenia albiflora (Hook.) } \\
\text { Reichb. ex Meisn. }\end{array}$ & Pissumar & Herb & Leaf paste is applied on cuts and wounds, root powder is used as antiseptic and juice given in vomiting and dysentery. \\
\hline Skimmia anquetilia. Taylar \& Airy & Nair patti & Shrub & Leaves are chewed for cooling effects, as well as mixed with other ingredients to manufacture incense dhup. \\
\hline Zanthoxylum aromatum DC. & Timroo & Tree & $\begin{array}{l}\text { Leaves and fruits are chewed for mouth wash and tooth care. Walking sticks are made from the stem, sometimes kept in the house } \\
\text { doors, believed to get rid of all evils, bark used for intoxicating the fishes and, flowers are important source of bee forage in apiary. }\end{array}$ \\
\hline
\end{tabular}




\section{Oxalidacea}

Oxalis corniculata Linn.

Oxalis dehradunensis Raizada in

Suppl. Duthie's Fl. U. Gang.

\section{Geraniaceae}

Geranium nepalense Sweet.

Geranium wallichianum D.Don ex

Sweet.

Balsaminaceae

Impatiens thomsonii Hook.

Araliaceae

Hedera nepalensis $\mathrm{K}$. Koch

\section{Apiaceae}

Bupleurum hamiltonii Balakrishnan.

Centilla asiatica Linn.

Bhilmori,

Khati-Buti

Khatura

Ratanjot

$-$

Laguli

Brahmi

Pimpinella diversifolia DC.

Selinum candollii DC.

\section{Gentianaceae}

Gentiana aprica Decne.

Gentiana capitata Buch.-Ham. ex

D.Don.

Gentiana pedicellata (D.Don.)

Wallich ex Grisebach.

Gentianella contorta Royle.

Swertia angustifolia Buch.-Ham. ex Chirata

D.Don.

Swertia cordata (D.Don.) C.B. Clarke Chratu

in Hook. f.

Swertia chirayita (Roxb.ex Fleming). Chrayata

Vern.

Swertia paniculata Wall.

Apocynaceae

Quirivella frutescens (Linn.) M.R. and Bel-kami S.M. Almeida,

Solanaceae

Solanum erianthum D.Don.
Herb Leaves are taken as salad or cooked as vegetables and leaf juice is dropped in cataract and conjunctivitis.

Herb A fine paste of the top shoot along with a few fruits of black pepper is applied to boils, abscesses wound and weeping eczema, also relives in abscess of the breast.

Herb Plant infusion is used in fever and renal disorders; roots paste applied externally on itching and eczema; rot in tanning industry.

Herb Root juice in diarrhea and ophthalmic, red dye obtained from the roots said to promote growth of hairs, as well as dye to woolen clothes.

Herb Seed edible powder of roasted seed with honey given to relieve cough and cold.

Climber Leaf and fruit paste are applied on ulcers and leaf juice given in dyspepsia.

Herb Roots are used in stomach and liver disorders and plant browsed by cattle.

Herb Plant juice or powder is used in the treatment of mental disorders and as a blood purifier; herb is regarded as a tonic and diuretic; leaf paste is applied for skin diseases including leprosy.

Herb Plant extract is given in digestive disorders and as well as in cold and cough

Bhutkeshi, Herb Root powder with honey is useful in cough and asthma and incense of root beneficial in hysteria.

Chirotu Herb Plant juice with flower decoction of Viola sp. is given in tea as a remedy of intermittent fever and headache.

Herb

Chhoti buggi Herb

Herb

Herb Plant extract is used as a tonic and febrifuge and used as substitute for original 'Chiryata'.

Herb Plant is used as substitute for 'Chirayita'.

Herb The plant is well known for Ayurvedic medicine "Chretta" which is used in blood diseases and as febrifuge.

Herb Plant is used as substitute of 'Chirayata'.

Shrub Branches are made into baskets, leaf extract is supposed to be febrifuge and paste applied in leucoderma. Flowers are used as a source of bee-forage in apiary.

Shrub Roots, leaves and fruits after heating are applied on wounds and burns, extract chiefly used in urinary troubles and skin diseases. Fruits occasionally eaten. 


\begin{tabular}{|c|c|c|c|}
\hline \multicolumn{4}{|l|}{ Verbenaceae } \\
\hline Callicarpa macrophylla Vahl. & Daiya & Shrub & $\begin{array}{l}\text { Edible fruits, useful in oral aphthae, leaves after heating are applied externally on rheumatic pain and flowers are used as a source } \\
\text { of bee forage. }\end{array}$ \\
\hline Caryopteris foetida (D.Don) Thellung. & Karwi & Shrub & Used as fodder, leaf juice applied on wounds and flowers as source of bee-forage \\
\hline \multicolumn{4}{|r|}{ 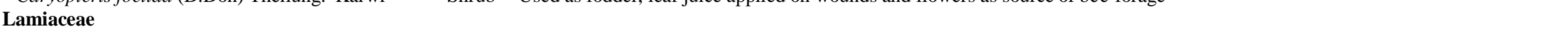 } \\
\hline $\begin{array}{l}\text { Ajuga bracteosa Wallich ex Benth. in } \\
\text { Wallich. }\end{array}$ & Neelkanthi & Herb & Leaf extract is used in malarial fever, bitter plant extract is used as a tonic, astringent, and febrifuge. \\
\hline $\begin{array}{l}\text { Clinopodium umbrosum (M. Bieb.) C. } \\
\text { Koch in Linnaea. }\end{array}$ & - & Herb & $\begin{array}{l}\text { Plant extracts are used as an astringent, carminative and as blood purifier, leaves infusion is used in gastric troubles and flowers as } \\
\text { a source of bee-forage. }\end{array}$ \\
\hline Leucas lanata Benth. in Wallich. & Bis-kapra. & Herb & Plant infusion is given with honey in the treatment of whooping cough and young shoots cooked as vegetable. \\
\hline $\begin{array}{l}\text { Micromeria biflora (Buch.-Ham. ex } \\
\text { D.Don) Benth. }\end{array}$ & Gorakhopan & Herb & - \\
\hline Micromeria capitellata Benth. in DC. & Van ajwain & Herb & Flavor of crushed leaves is inhaled in cold and sinusitis, extract of leaves with milk given in gastro-enteritis. \\
\hline $\begin{array}{l}\text { Nepeta ciliaris Wallich ex Benth. in } \\
\text { Wallich. }\end{array}$ & Nueet & Herb & Decoction of leaves and seeds is taken in fever. Leaves also yield essential oil. \\
\hline Origanum vulgare Linn. & Bantulsi & Herb & $\begin{array}{l}\text { Plant extract is used in bronchitis, colic and diarrhea, leaves eaten as vegetable and flavoring agent, flowering branches hung on the } \\
\text { houses to get rid of bad spirits. }\end{array}$ \\
\hline Plectranthus mollis (Aiton) Sprengel & & Herb & Flowers as a source of bee forage. \\
\hline $\begin{array}{l}\text { Pogostemon benghalense (Burm. f.) } \\
\text { Kuntze }\end{array}$ & $\begin{array}{l}\text { Kala- } \\
\text { Basingu }\end{array}$ & Shrub & Leaf extract in water is given in colic and fever, flower important source of bee-forage and plant is a good soil binder. \\
\hline Prunella vulgaris Linn. & Ust-khadus & Herb & Extract of the herb is used in gastric and breathing problems. \\
\hline $\begin{array}{l}\text { Rabdosia lophanthoides (Buch.-Ham. } \\
\text { ex D.Don.) Hara. }\end{array}$ & - & Herb & - \\
\hline $\begin{array}{l}\text { Rabdosia rugosa (Wallich ex Benth.) } \\
\text { Hara. }\end{array}$ & Chhenchneri & Shrub & Decoction of leaves is used in fever and flowers are important source of bee forage. \\
\hline Salvia lanata Roxb. & Ghanyajhar & Herb & Leaf infusion is given in colic and diarrhea, flower paste used in cold and cough and flower as a source of bee-forage. \\
\hline $\begin{array}{l}\text { Scutellaria scandens Buch.-Ham ex } \\
\text { D.Don. }\end{array}$ & Kutlaphul & Herb & Flowers as a source of bee forage. \\
\hline $\begin{array}{l}\text { Teucrium quadrifarium Buch.-Ham. } \\
\text { ex D.Don. }\end{array}$ & Bilmga & Shrub & Root chewed for sore throat, infusion of leaves used as abortifacient. \\
\hline \multicolumn{4}{|l|}{ Plantaginaceae } \\
\hline Plantago erosa Wall. & - & Herb & - \\
\hline Plantago depressa Willd. & Luhurya & Herb & Paste from leaves and seeds are applied on cuts wounds and piles; plant part tied around the belly of infant for good health \\
\hline \multicolumn{4}{|r|}{ 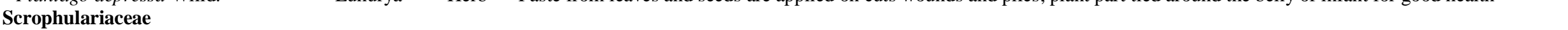 } \\
\hline Hemiphragma heterophyllum, Wall. & - & Herb & - \\
\hline Mazus surculosus D.Don & - & Herb & - \\
\hline Misopates orontium (Linn.) & Weasel's & Herb & Plant is believed to be poisonous to cattle. \\
\hline Rafinesque-Schmaltz, & Snout & & \\
\hline $\begin{array}{l}\text { Pedicularis punctata } \text { Decne. in } \\
\text { Jacquem. }\end{array}$ & - & Herb & - \\
\hline $\begin{array}{l}\text { Scrophularia himalensis Royle ex. } \\
\text { Benth. }\end{array}$ & Sikula & Herb & Leaves are mixed with stored grains as an insecticide. \\
\hline
\end{tabular}




\begin{tabular}{|c|c|c|c|}
\hline \multicolumn{4}{|l|}{ Acanthaceae } \\
\hline Barleria cristata Linn. & $\begin{array}{l}\text { Saundi, } \\
\text { Kala-bansa }\end{array}$ & Shrub & $\begin{array}{l}\text { Root decoction is used against bronchitis and pneumonia; leaves and root paste is applied on wound-swelling, root chips are added } \\
\text { to local beverages, seeds are regarded as antidote to snake bite, flowers as a source of bee forage and plant act as soil binder. }\end{array}$ \\
\hline $\begin{array}{l}\text { Dicliptera bupleuroides Nees in } \\
\text { Wallich. }\end{array}$ & Kulartore & Herb & $\begin{array}{l}\text { The plant is used as fodder, leaf paste is applied on wounds to check bleeding, leaf juice useful in cough and gastroenteritis. } \\
\text { Flowers as a source of bee-forage in apiary. }\end{array}$ \\
\hline $\begin{array}{l}\text { Lepidagathis incurva Buch.-Ham. ex } \\
\text { D.Don. }\end{array}$ & - & Herb & - \\
\hline $\begin{array}{l}\text { Pteracanthus angustifrons (C.B. } \\
\text { Clarke) Bremekamp. }\end{array}$ & Pathora & Shrub & - \\
\hline \multicolumn{4}{|l|}{ Campanulaceae } \\
\hline Cynanthus integer Wall. & - & Herb & - \\
\hline Cynanthus lobatus & - & Herb & - \\
\hline \multicolumn{4}{|l|}{ Rubiaceae } \\
\hline Galium asperifolum Wallich in Roxb. & Liswa kuri & Herb & Plants paste is used fuel for skin ailments. \\
\hline Galium aparine Linn. & $\begin{array}{l}\text { Khuskusa, } \\
\text { Kuri }\end{array}$ & Herb & Extract of leaves is used as astringent and plant paste applied on skin diseases. \\
\hline Galium elegans Wallich in Roxb & Manjeethee & Herb & Plant extract is given in colic, dyspepsia and as well as in jaundice. \\
\hline Leptodermis lanceolata Wall. & Padera & Shrub & $\begin{array}{l}\text { Occasionally browsed by cattle; bark paste is externally applied in migraines; flowers as an important source of bee - forage in } \\
\text { apiculture. }\end{array}$ \\
\hline $\begin{array}{l}\text { Rubia manjith Roxb. ex Fleming in } \\
\text { Asiat. Res. }\end{array}$ & Majethi & Climber & $\begin{array}{l}\text { Dye commercially known as Manjit, extracted from the root and stem, roots medicinal, as tonic and astringent, stem used as an } \\
\text { antidote to snakebite and flower extract in bacillary dysentery. }\end{array}$ \\
\hline Spermodictyon suoveolens Roxb. & Padera & Shrub & $\begin{array}{l}\text { Root powder or extract is given in diarrhea and cholera. Leaves as fodder and are also used as insecticide for the stored grains and } \\
\text { flowers as an important source of bee-forage. }\end{array}$ \\
\hline \multicolumn{4}{|r|}{ (1) } \\
\hline Valeriana hardwickii Wallich in Roxb. & Somaya & Herb & $\begin{array}{l}\text { Root decoction is used in urinary disorders; paste is applied externally in joint pains. Dried roots are used as incense and } \\
\text { insecticide. }\end{array}$ \\
\hline $\begin{array}{l}\text { Valeriana jatamansii Jones in Asiat. } \\
\text { Res. }\end{array}$ & Balchari & Herb & $\begin{array}{l}\text { Roots are used as an aphrodisiac and in mental disorders, as well as in local beverages to promote aroma. Dried roots are also used } \\
\text { as an incense and insecticide }\end{array}$ \\
\hline \multicolumn{4}{|l|}{ Dipsacaceae } \\
\hline $\begin{array}{l}\text { Morina longifola Wallich ex DC. } \\
\text { Asteraceae }\end{array}$ & Biskandaru. & Herb & Root paste is applied externally on wounds dried roots burnt as incense; the aroma of the flower believed to cause unconsciousness \\
\hline Ageratum conyzoides Linn. & Gundrya & Herb & Plants with the root of Thallictrum foliosum made into paste and applied on sores, cuts and various skin ailments. \\
\hline $\begin{array}{l}\text { Ainsliaea latifolia (D.Don) Schultz- } \\
\text { Bipontinus in Jahresber }\end{array}$ & Kauru & Herb & Decoction of roots is given in colic \\
\hline Anaphalis adnata Wallich. & Bugla & Herb & $\begin{array}{l}\text { Paste of head and leaves is applied on cuts, wounds and boils, Fibers of leaves and stem used to lit the fire by friction of stones, } \\
\text { locally known as Agela. }\end{array}$ \\
\hline $\begin{array}{l}\text { Anaphalis contorta (D.Don) Hook. F. } \\
\text { in Fl. Brit. India }\end{array}$ & Bugla & Herb & Paste of heads and leaves is applied on cuts, wounds and boils. Smokes of plants are used as insect repellent. \\
\hline $\begin{array}{l}\text { Anaphalis triplinervis (Sims) C.B. } \\
\text { Clarke in Comp. Indicae }\end{array}$ & Buglya & Herb & Leaf juice is dropped in laceration of toes during rainy season. Paste of heads and leaves is applied on cuts, wounds, and boils. \\
\hline Artemisia capillaris Thunb. & Jhirun & Herb & Decoction of leaves is taken as a bitter tonic for worms and colic, twigs used as brooms. \\
\hline
\end{tabular}




\begin{tabular}{|c|c|c|c|}
\hline Aster molliusculus (Lindley ex DC.) & - & Herb & - \\
\hline Aster peduncularis Wallich ex Nees. & Phulyan & Herb & xtract of plant is believed to be useful to dissolve renal-calculi and root powder as stomachic. \\
\hline Bidens pilosa Linn. & Kumra & Herb & $\begin{array}{l}\text { Plant extract with honey used in cough and bronchitis, the vegetable of the herbs considered useful in leucoderma and plants } \\
\text { browsed as fodder. }\end{array}$ \\
\hline Cicerbita cyanea (D.Don) G. Beauv. & - & Herb & - \\
\hline Cicerbita macrorhiza (Royle) G. Beauv. & - & Herb & - \\
\hline $\begin{array}{l}\text { Conyza japonica (Thunb.) Lessing ex } \\
\text { DC. }\end{array}$ & - & Herb & - \\
\hline Elephantopus scaber Linn. & Adhomukha & Herb & Root extract is used in intermittent fever and to stop vomiting and leaves as tonic of blood diseases. \\
\hline Emilia sonchifolia (Linn.) DC. in Wight. & - & Herb & 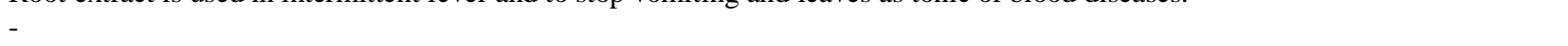 \\
\hline Erigeron sublyratus DC. in Wight. & $\begin{array}{l}\text { Hirankuri, } \\
\text { Dudhi. }\end{array}$ & Herb & $\begin{array}{l}\text { Occasionally upper leaves are cooked as vegetable. Herbs are used as febrifuge and leaf juice used in eye inflammation and night } \\
\text { blindness. }\end{array}$ \\
\hline Eupatorium adenophorum Sprengel. & $\begin{array}{l}\text { Kharna, } \\
\text { Bakura }\end{array}$ & Shrub & An obnoxious introduced weed occupying large grassy localities reducing fodder produce. Crushed leaves are applied on wounds. \\
\hline Gerbera gossypina (Royle) G. Beauv. & Kapasee & Herb & $\begin{array}{l}\text { Leaf juice is applied on wounds and cuts and paste plastered on bone fracture. In old days, fiber was used to manufacture coarse } \\
\text { cloth for sacs and mats and also used to burn fire. }\end{array}$ \\
\hline Gnaphalium hypoleucum DC. in Wight. & Buglya & Herb & Plant extract is applied on cuts and wounds, plant juice is applied on breast and believed to increase lactation. \\
\hline Gnaphalium pensylvanicum Willd. & - & Herb & - \\
\hline $\begin{array}{l}\text { Inula cappa (Buch.-Ham. ex D.Don.) } \\
\text { DC. }\end{array}$ & $\begin{array}{l}\text { Athhu, } \\
\text { Tamagari }\end{array}$ & Shrub & Roots are given in suppressed urination. \\
\hline Lactuca dissecta D.Don. & - & Herb & - \\
\hline $\begin{array}{l}\text { Myriactis nepalensis Lessing in } \\
\text { Linnaea. }\end{array}$ & Bakura & Herb & Leaves and young shoots are occasionally used as vegetable \\
\hline $\begin{array}{l}\text { Pentanema indicum (Linn.) Ling in } \\
\text { Acta Phyt. }\end{array}$ & - & Herb & - \\
\hline $\begin{array}{l}\text { Saussurea auriculata (Sprengel ex } \\
\text { DC.) Schultz-Bipontinus in Linnaea, }\end{array}$ & $\begin{array}{l}\text { Thimra, } \\
\text { Nurya }\end{array}$ & Herb & Leaf paste of the plant along with the leaves of Betula utilis is used externally in venereal diseases. \\
\hline $\begin{array}{l}\text { Saussurea heteromalla (D.Don.) } \\
\text { Hand.-Mazz. }\end{array}$ & Murang & Herb & Leaf paste with mustard oil is massaged on leucoderma and wounds and root extract is taken in fever and colic. \\
\hline Senecio graciliflorus DC. & - & Herb & $\begin{array}{l}\text { Plant paste is applied on insect bites and ringworm diseases; juice of head dropped in pussed ear; plant believed to be poisonous to } \\
\text { cattle }\end{array}$ \\
\hline Siegesbeckia orientalis Linn. & Liskura & Terb & ecoction of plant with rice waters is taken in diarrhea and bowel complaints. \\
\hline Solidago virgaurea Linn. & Pinja-phool & Herb & $\begin{array}{l}\text { Juice of leaves is given in kidney troubles, decoction of whole herb is used for treatment of asthma, rheumatism, and wounds and } \\
\text { root chewed in throat irritation. }\end{array}$ \\
\hline Sonchus asper (Linn.) Hill. & $\begin{array}{l}\text { Pili-dudhi, } \\
\text { Choplya }\end{array}$ & & The plant is used as a tonic to purify blood and in hepatitis and leaf paste applied on wounds. \\
\hline Sonchus brachyotus DC. & Karatu & Herb & Roots are used in folk medicine against cough and bronchitis. Young shoots and leaves are used as vegetable in famine. \\
\hline Tagetes minuta Linn. & Jangli genda & Herb & 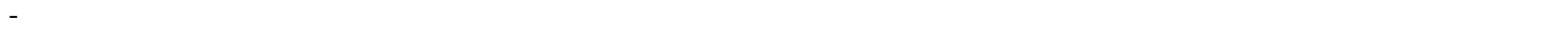 \\
\hline $\begin{array}{l}\text { Taraxacum officinale Weber in } \\
\text { Wiggers }\end{array}$ & Kanphuliya & Herb & $\begin{array}{l}\text { Root extract is used in the treatment of migraine, hepatitis, and headache. Young shoots and leaves are thoroughly boiled and } \\
\text { cooked as vegetable. }\end{array}$ \\
\hline
\end{tabular}




\section{MONOCOTYLEDONEAE}

Araceae

Acorus calamus Linn.

Arisaema intermedium Blume.

Buch, gud

buch

Meen

Cyperaceae

Carex aristata Tilloch and Taylor.

Cyperus niveus Retz.

Cyperus nutans Vahl in Enum

Cyperus rotundus Linn.

Kobresia laxa Nees in Wight, Contrib.

Scirpus ternatanus Reinwardt ex Mi

Poaceae

Apluda aristata Linn

Brachiaria reptans (Linn.) Gardner

and C.E. Hubbard in Hook.

Brachiaria villosa (Lam.) A. Camus in Malchu

Lecomte.

Chrysopogon aciculatus (Retz.) Surwala or

Trinius.

Cynodon dactylon (Linn.) Persoon. Dubla

Dichanthium annulatum (Forsk.) Stapf -

in Prain

Eragrostis nigra Nees. ex Steudel.

Eulalia trispicata (Schultes.) Henrard

in Blumea.

Heteropogon contortus (Linn.) P.

Beauv, ex Roemer \& Schultes

Poa annua L

Saccharum filifolium Steudel.

Setaria viridis (Linn.) P. Beauv.

Sporobolus diander (Retz) P. Beau

Zingiberaceae

Hedychium spicatum Buch.-Ham. ex Kapoor

J.E. Smith in Rees

Roscoea purpurea J.E. Smith

Liliaceae

Asparagus racemosus Willd

Polygonatum cirrhifolium (Wallich)

Royle.

Theropogon pallidus (Kunth) Maxim.

ghas

Medha
Stolons -

ya-ghas Herb

Herb

Herb - Dried underground parts used in perfumes and plant extract used as diaphoretic and astin

Herb

Herb Used as fodder when young.

Herb -

Herb

Used as fodder to milching animals.

As fodder but sharp callus intermingled with the body of cattle.

Herb Plant is believed pious and used in several religious ceremonies.

Herb Excessively used as fodder.

Herb -

Herb -

Kumrya- Herb Grass stored as fodder for the period of scarcity.

Herb

The grain edibles hay and green grass as fodder.

Herb Crushed leaves are applied on burns and pimples and good soil binder and also provide fodder.

Herb Boiled underground parts ate with salt, roasted powder of rhizome given in asthma, seeds believed to cause abortion and decoction

Kachari $\quad$ of rhizome with sawdust of deodara taken in tuberculosis.

Satavari, Herb Root aphrodisiac, antiseptic, refrigerant is often used with freshwater or milk. Root decoction with jaggery used an abortifacient.
Herb Leaves are eaten as vegetable; root infusion with milk used as an aphrodisiac and blood purifier; paste in cut and wound. 


\section{Smilaceae}

Smilax aspera Linn.

\section{Dioscoreaceae}

Dioscorea belophylla (Prain) J.O.

Dioscorea bulbifera Linn.

Orchidaceae

Calanthe plantaginea Lindley.

Coelogyne cristata Lindley.

Dactylorhiza hatagirea (D. Don.) Soo Hattarjari

Nom

Dandrobium monticola P.F.

Habenaria intermedia D.Don

Nervillia prainiana King and Pantling.
Kukurdara Climber Occasionally young leaves are cooked. Roots are diuretic and diaphoretic. Root paste with mustard oil massaged on rheumaticarthritis and flowers as a source of bee-forage.

Tairu Climber Tuber edible as well as medicinal much liked by wildlife.

Genthi Climber Tuber are cooked as vegetable. Dried tuber used as an antiseptic, applied on burns and wounds, flowers occasionally visited by bee

Herb

Herb Infusion of pseudobulbs given in constipation and also as an aphrodisiac

Herb Used in Aphrodisiac and tonic.

Herb

Herb - 


\section{Discussion}

The study area is rich in plant biodiversity corresponding to the climate and topography of the area. The area has temperate vegetation with altitudes ranging from 1500-2200 m asl. Different factors have influenced (lower or exceeded) the normal limit of vegetation type and flowering seasons. Natural vegetation in vicinity of towns and villages in the subtropical belt has been subjected to face more biotic disturbances as compared to the villages at high elevations. There is abundance of grasses and annuals during monsoon, whereas perennials, shrubs, and trees mostly bloom during spring and summer (Bisht and Sharma 2014).

The most attractive part of vegetation in the study area was the presence of numerous medicinal plant species, the fact is generally ignored by scientists. Each plant species has its own value in the form of fodder, and vegetables, flowers as bee forage, resin, tannin, gum, dye, ornamentation, psychomedicine, and medicines, etc. A total of 274 species, near about 47 species were also purely medicinal and used in the form of leaves, stem, bark, root, flowers, fruits, seeds, and whole plant. These plant species are used against dropsy, bronchitis, boils and wounds, insect and snake bite, relieve from suffering of nettle sting, malarial fever, facilitate delivery, body pain, rheumatism, fever, cold and cough, gonorrhea, colic and dyspepsia, diarrhea, digestive and respiratory disorders, diabetes and urinary ailments, relieving earache, body swelling and contusions, psych medicines, treatments of migraines, hepatitis and headache, dysentery, etc. by villagers and Vaishyas. Some important species include Achyranthus bidentata, Agrimonia pilosa, Anaphalis contorta, A. triplinervis, Aster peduncularis, Anemone vitifolia, Argemone ochroleuca, Asparagus recemosus, Berberis aristata, Barleria cristata, Begonia picta, Bupleurum hamiltonii, Clematis buchananiana, Coccinia grandis, Coelogyne cristata, Cyathula tomentosa, Gerbera gossypina, Gnaphalium hypoleucum, Hedychium spicatum, Inula cappa, Jasminum humile, Leucus lanata, Saussurea heteromalla, Senecio graciliflorus, Siegesbeckia orientalis, Solidago virgaurea, Sonchus asper, Swertia cordata, and Taraxacum officinale.

The extinction of these medicinal plants from their natural habitat is a matter of great concern but it has not attracted the attention of naturalists and environmentalists. This is probably because the medicinal wealth of this area is little known hence no agency or related departments care for the protection and management of these continuously declining species of drug importance. Changing atmospheric conditions and lack of knowledge, infectious nature of some dominating weeds e.g Eupatorium adenophorum and Parthenium sp. are among the other factors responsible for the extinction of these important medicinal plant species. (Bisht 2005; Bisht and Bhatt 2012). Due to lack of awareness about medicinal importance of these weeds they are discarded by the farmers. These weeds can become an additional source of income for the farmers, if they are made aware of the medicinal importance of these crop weeds (Bisht et al 1988).
The important medicinal plant species in Bharsar, a total of 34 medicinal plant species belonging to 32 genera and 25 families were collected and recorded for their use in various ailments. Most of the local people in the study area are poor and illiterate. On one hand, these people are out of the reach of modern medicines and on the other hand, the market prices of most available medicines are very expensive. As a result, these medicinal plants are used to cure following diseases, especially for abscess, asthma, abortion, cough, cold, smallpox, dysentery, diarrhea, diabetes, eczema, fever, itches, jaundice, menstrual disease, paralysis, piles, skin diseases, snake-bite, toothache, worm, wound and others.

The study reveals that local people still depend on a number of plants for their daily needs especially medicine. Among identified medicinal trees, most of them are commonly found near the villages surrounding, wasteland, and forest areas. Plants of scientific knowledge, which have been investigated pharmacologically and chemically, and their active principle are used in modern medicine or provide valuable leads for partial or total synthesis of new drugs(Dhar et al. 2002; Parkash et. al.2002).

Despite their significance to rural livelihoods, the abundance and diversity of understory medicinal plant species are threatened by changes in the structural attributes of the cover story in native old-growth forests as a result of degradation (Galliam 2007). Therefore, the present study adds new knowledge on ethnobotanical uses of Angiosperm plants from Bharsar and adjoining area of district Pauri Garhwal. People in this region are partially or completely dependent on forest resources for medicine, food, fuel, and fodder. A great deal of traditional knowledge of the use of various plant species is still intact with the indigenous people, and this fact is especially relevant with the mountainous areas such as the Himalayas due to less accessibility of terrain and comparatively slow rate of development (Farooquee et al. 2004).

Convention on Biological Diversity states that indigenous people play a vital role in environmental management and development through their traditional practices. It requires nation to protect the traditional knowledge and customary practices related to the use of biological diversity (Glowka et.al.1997).

\section{REFERENCES}

Atkinson ET. 1882. The Himalayan Gazetteer, Vol. 2 (reprint 1973), Cosmo Pub. Delhi.

Badoni AK. 1990. Remarks on the high-altitude medicinal plants of Garhwal Himalayas. J Himalayan Stud Reg Dev 13 \&14: 37-45.

Bisht AS, Bhatt AB. 2012. A contribution of the medicinal plants of Sahastradhara, district Dehradun, Uttarakhand (with ethnobotanical Notes). J Drug Deliver Therapeut 2 (5): 114-120. DOI: DOI: 10.22270/jddt.v2i5.261

Bisht AS, Sharma KD. 2014. Plants utilization by the communities of Bharsar and adjoining area of Pauri Garhwal District, Uttarakhand, India. Biodiversitas 15 (1) 94-100. DOI: 10.13057/biodiv/d150114..

Bisht AS. 2005. Ecological Studies of Some Important Medicinal Herbs; Their Multiplication and Conservation in Garhwal Himalaya, India, [Dissertation]. Garhwal University, Srinagar (Garhwal), Uttarakhand.

Bisht MK, Bhatt KC, Gaur RD. 1988. Folk medicines of Arakot valley in district Uttarkashi: an ethnological study. In Purshottam Kaushik (ed) 
Indigenous Medicinal Plants. Today Tomorrow Printers and Publishers, New Delhi.

Burkill IH. 1965. Chapters on the History of Botany in India. BSI, Howrah.

Cronquist A. 1981. An integrated system of classification of flowering plants. Columbia University Press New York.

Dhar U, Manjkhola S, Joshi M. 2002. Current status and future strategy for development of medicinal plants sector in Uttaranchal, India. Curr Sci 83: 956-964.

Farooquee NA, Majila BS, Kala CP 2004. Indigenous knowledge systems and sustainable management of natural resources in a high-altitude society of Kamaun Himalaya, India. J Hum Ecol 16: 33-42. DOI: 10.1080/09709274.2004.11905713.

Gaur RD. 1999. Flora of the District Garhwal North West Himalaya (with ethnobotanical notes). Transmedia, Srinagar Garhwal, Uttaranchal, India.

Gilliam FS 2007. The ecological significance of the herbaceous layer in temperate forest ecosystems. Bioscience. 57:845-858. DOI: 10.1641/B571007.
Glowka L. 1997. A Guide to designing legal frameworks to determine access to genetic resources, the world conservation union, IUCN, Gland, Switzerland.

Naithani BD. 1985. Flora of Chamoli. 2 Vols. BSI, Calcutta.

Negi KS, Gaur RD, Tiwari JK.. 1999. Ethnobotanical notes on the flora of Har Ki Doon (District Uttarkashi. Garhwal Himalaya, U.P. India Ethnobotany 5 (1\&2): 73-81. DOI: 10.1080/21513732.2011.575385

Parakash V. 2002. Himalayan Medicinal Plants Potential and Prospect (eds.), GyanodayaPrakashan, Nanital.

Rao R R. 1994. Biodiversity in India (Floristic aspects) II. Bishen Singh \& Mahendra Pal Singh, Dehra Dun.

Rao RR. 1994. Biodiversity in India (Floristic aspects) I. Bishen Singh \& Mahendra Pal Singh, Dehra Dun.

Rawat DS, Bhandari BS, Gaur RD. 2001. Vegetation Wealth. In: Kandari OP, Gusain OP (eds.) Garhwal Himalaya Nature, Culture and Society. Transmedia House, Pub. Co., Srinagar, Garhwal.

Samant SS, Dhar U, LMS Palni,. 2001. Himalayan Medicinal Plants Potential and Prospects. Gyanodaya Prakashan, Nainital.

Samant SS, Dhar U, Palni LMS. 1998. Medicinal plants of Indian Himalaya: Diversity Distribution Potential value. Gyanodaya Prakashan, Nainital. 